\title{
Wychowanie moralne i religijne ubogich i sierot w Krakowskim Towarzystwie Dobroczynności w latach 1816-1918
}

\section{The Religious and Moral Education of the Poor and Orphans in the Krakow Charity Association in the Years 1816-1918}

\begin{abstract}
ABSTRAKT
Celem artykułu jest przedstawienie realizowanego przez Krakowskie Towarzystwo Dobroczynności wychowania moralnego i religijnego ubogich. W zakładzie Towarzystwa mieszkali ludzie starzejacy się i starzy, z problemami zdrowotnymi, którzy nie mogli już z braku sił zapracować na własne utrzymanie. Podopiecznymi były również sieroty od 10. do 16. roku życia (po 1874 roku przyjmowano nawet dzieci sześcioletnie). Organizowano dla nich opiekę, ale również kładziono nacisk na eliminowanie negatywnych zachowań i przyzwyczajeń, nakłaniano do moralnego i zgodnego z naukq chrześcijańska życia. Analiza materiałów źródłowych, zwłaszcza statutów, regulaminów i instrukcji pozwoliła na ukazanie, w jaki sposób wychowywano podopiecznych na „pożyłecznych członków społeczności”. Walczono zwłaszcza z próbami żebrania oraz nadużywaniem alkoholu. Przyimując do zakładu ubogich, sprawdzano, czy ich życie było zgodne
\end{abstract}

SPI Vol. 19, 2016/2

ISSN 2450-5358

e-ISSN 2450-5366

DOI: 10.12775/SPI.2016.2.003

Artykuły i rozprawy 
z normami moralnymi oraz czy były one pracowite. Wypełniano dzień ubogich modlitwa, praca, dbano aby właściwie spędzali czas wolny. Zwracano uwagę na wzajemnq życzliwość, szacunek względem dobroczyńców oraz siebie nawzajem. Uczono porzqdku, troski o rzeczy własne, jak również należq̨ce do Towarzystwa. Brak przestrzegania regulaminów był karany. Kary miały określonq gradację, zawsze starano się najpierw udzielać upomnień. Motywacja do właściwego postępowania były nagrody. Nagradzano za pracę, naukę, umożliwiano uroczyste obchodzenie świq̨t kościelnych. Dla sierot organizowano majówki, wycieczki. Wyrażano zgodę na urlopy, odwiedzanie rodzin.

\section{ABSTRACT}

The aim of the article is to present implemented in $19^{\text {th }}$ century by the Cracow Charitable Society the moral and religious education of the poor. In the plant of the Society lived aged and old people, with health problems, who lacked of their own forces to earn for living. Wards were also the orphans from 10 to 16 years old (after 1874 the Society accepted even six years old children). The daily care for them was organized, with putting the emphasis on eliminating negative behaviors and habits, they were urged to live a life in accordance with the moral and Christian values. Analysis of source materials, especially the statutes, regulations and instructions made it possible to show how the wards were brought up in order to be in the future the "useful members of the community". The staff of the Society fought especially with attempts of begging and alcohol abuse. During the enrolment the staff checked if the candidates' behaviour was in line with moral standards and if they were diligent enough. Daily routine was carefully planned: there was a time of prayer, of work, care was taken to spend in a fruitful manner free time. The staff stressed the value of mutual kindness, respect shown to each other, and towards the benefactors. The wards were taught how to care for their own belongings and for what the Society provides to them. Failure to comply with regulations was punished. Penalties had a definite gradation, the staff always sought to give reprimands first. The system of awards and compensations was introduced in order to motivate pupils for proper conduct. They were rewarded for diligent work, learning, and allowed to participate in celebration of religious holidays. For orphans the picnics, tours were organized. The permission to see families and to go on holidays were also given. 


\section{Wprowadzenie}

Towarzystwo Dobroczynności w Krakowie powołane zostało w 1816 roku i działało do czasu rozwiązania go przez ówczesne władze w roku $1951^{1}$. Udzielało pomocy ludziom starym, chorym, kalekim, którzy nie mogli zarobić na swoje utrzymanie, wspomagało również sieroty, chłopców i dziewczęta. W Domu Schronienia Ogólnego zapewniano im mieszkanie, wyżywienie, ubranie, a dzieciom umożliwiano ponadto zdobycie podstaw wykształcenia w założonej szkole zakładowej oraz przygotowanie do wykonywania pracy zarobkowej. Na protektora Krakowskiego Towarzystwa Dobroczynności (dalej: KTD) zapraszano biskupa krakowskiego, kierował nim prezes wraz z Radą Ogólną. Poszczególne zadania podzielone zostały pomiędzy wydziały, które wspomagali tzw. urzędnicy płatni Towarzystwa. W drugiej połowie XIX wieku normowano funkcjonowanie urzędników płatnych Towarzystwa odrębnymi instrukcjami. W 1912 roku rozwiązano szkołę zakładową, w której kształcono sieroty w zakresie szkoły elementarnej od roku 1817. W zakładzie nadal wspierał przygotowania do nauki nauczyciel, nad poprawnym zachowaniem podopiecznych od początku XX wieku czuwały Siostry Miłosierdzia. Zastąpiły one świeckie ochmistrzynie, które niemalże od początku istnienia Towarzystwa sprawowały nadzór wraz z nauczycielem nad dziećmi. W pracy z dziećmi zwracano uwagę na wiedzę, jaką powinny posiadać po ukończeniu szkoły, ale istotne również było realizowanie zadań wychowawczych, zwłaszcza w zakresie umoralniania podopiecznych, jak i doskonalenia ich postawy religijnej.

Przedmiotem badań w niniejszym artykule są dzieje Towarzystwa, ze szczególnym uwzględnieniem opieki i wychowania w latach 1816-1918. Celem artykułu jest ukazanie, w jaki sposób realizowano

1 Archiwum Narodowe w Krakowie (dalej: AN Kraków), Protokoty posiedzeń z lat 1921-1940 r., sygn. 11, 390 k. Po 1918 roku kontynuowano działalność dobroczynną, opiekowano się nadal osobami starszymi i dziećmi, ale już w nowych, zmienionych warunkach politycznych. Jak wynika ze źródeł, już od 1933 roku, po opuszczeniu zakładu przez ostatnie dziewczęta, nie przyjmowano do niego kolejnych dzieci. W czasie II Rzeczpospolitej zmieniono nazwę zakładu KTD na „Dom Starców i Kalek”. Zob. AN Kraków, Urząd Wojewódzki Krakowski, Sygn. UW II 1098, Rejestracja stowarzyszeń z terenu Krakowa 1945-1950 (1951), IV/3/Krm/39/45, k. 173. Pismo Prezydium WRN informuje, że prawomocną decyzją z dnia 22 sierpnia 1951 roku orzeka się likwidację Krakowskiego Towarzystwa Dobroczynności. 
wychowanie moralne i religijne w zakładzie Krakowskiego Towarzystwa Dobroczynności, będącego jednym z najstarszych towarzystw dobroczynnych na ziemiach polskich. Badaniami objęto okres od utworzenia Towarzystwa w roku 1816 do roku 1918, czyli czas działalności dobroczynnej na rzecz ubogich pod zaborami.

$\mathrm{Na}$ temat Krakowskiego Towarzystwa Dobroczynności powstało kilka artykułów, których autorami są Ryszard Skowron, Józef Bąk, Ewa Barnaś-Baran². Wspominano o jego działalności również w opracowaniach poświęconych innym Towarzystwom Dobroczynności, które powstały w XIX wieku, bądź też przy okazji omawiania zagadnień związanych z organizacją opieki nad ludźmi ubogimi w okresie zaborów3.

Materiały źródłowe, które wykorzystano do opracowania problemu, zgromadzone są w Archiwum Narodowym w Krakowie. Materiały rękopiśmienne obejmują protokoły posiedzeń Rady Ogólnej Towarzystwa Dobroczynności za lata 1817-1918, regulaminy Domu Schronienia, instrukcje, akta urzędników płatnych Towarzystwa. Istotne znaczenie mają materiały drukowane, które również stanowią część zasobu wymienionego archiwum. Analizie poddano Roczniki Krakowskiego Towarzystwa Dobroczynności z lat

2 Zarys dziejów Krakowskiego Towarzystwa Dobroczynności w XIX wieku został ukazany w następujących artykułach: J. Bąk, Opieka spoteczna nad sierotami w Krakowskim Towarzystwie Dobroczynności w latach 1816-1916, „Rocznik Krakowski” 1975, t. 46, s. 99-112; R. Skowron, Towarzystwo Dobroczynności. Organizacja i dziatalność ogólnego domu schronienia ubogich na Wawelu (1816-1846), „Studia do Dziejów Wawelu” 1991, R. 5, s. 479-496; E. Barnaś, Powstanie i pierwsze lata dziatalności Krakowskiego Towarzystwa Dobroczynności (1816-1820), „Zeszyty Naukowe WSP w Rzeszowie. Pedagogika. Psychologia" 1997, z. 3, s. 87-99; E. Barnaś-Baran, Publiczny wizerunek krakowskich dobroczyńców ludzkości w XIX w., w: Mężczyzna w rodzinie i spoteczeństwie. Ewolucja ról w kulturze polskiej i europejskiej, t. 1: Od średniowiecza do poczatków XX wieku, red. K. Kabacińska, K. Ratajczak, Poznań 2010, s. 205-218.

3 A. Haratyk, Rozwój opieki nad dziémi i mtodzieżq w Galicji doby autonomicznej, Wrocław 2002, H. Markiewiczowa, Dziatalność opiekuńczo-wychowawcza Warszawskiego Towarzystwa Dobroczynności 1814-1914, Warszawa 2002; C. Kępski, Idea mitosierdzia a dobroczynność i opieka, Lublin 2002; M. Piotrowska-Marchewa, Nędzarze i filantropi. Problem ubóstwa w polskiej opinii publicznej w latach 1815-1863, Torun 2004; A. Puszka, Dziatalność opiekuńczo-wychowawcza Zakonu Sióstr Mitosierdzia Wincentego à Paulo w Lublinie w XIX i XX wieku, Lublin 2013. 
1826-1918, jak również statuty, instrukcje i regulaminy. Cenne informacje zaczerpnięto z publikacji Józefa Teodora Głębockie$\mathrm{go}^{4}$, sekretarza Towarzystwa, a także z pamiętnika wydanego w 50 . rocznicę powołania Towarzystwa ${ }^{5}$.

Jak zaznaczył Walery Wielogłowski, członek KTD, żebrakami proszącymi o wsparcie w Krakowie byli niejednokrotnie ludzie „upadli na duchu, sumieniu i obyczajach". Zwracał w ten sposób uwagę na wpływ stanu ubóstwa i żebrania na kondycję moralną człowieka. Uświadamiał, że podjęcie się organizacji opieki nierozerwalnie powinno być związane z troską o wychowanie ubogich dzieci i dorosłych. KTD udzielając wsparcia ubogim podjęło się również zadania wychowania podopiecznych przyjmowanych do zakładu. W jaki sposób zatem Krakowskie Towarzystwo Dobroczynności realizowało zadanie wychowania podopiecznych na wartościowych i pożądanych członków społeczeństwa?

\section{Kształtowanie moralne i religijne podopiecznych Towarzystwa Dobroczynności przez członków Wydziałów oraz urzędników Towarzystwa}

Dom Schronienia był zakładem, do którego przyjmowano przede wszystkim dorosłych ubogich, ale podjęto również opiekę nad sierotami ${ }^{7}$. Otwarto go 20 stycznia 1817 roku, a pierwszeństwo w stałym utrzymaniu otrzymali ludzie starzy, niesprawni fizycznie chorzy oraz sieroty i dzieci zubożałych rodziców ${ }^{8}$. Poza schronieniem i wyżywie-

4 J.T. Głębocki, Zakłady ku ulżeniu cierpieniom bliźnich obecnie w Krakowie istniejące. Z krótkq wzmiankq o dawniejszych, a dzis nie istniejacych instytucyach tego rodzaju, Kraków 1852.

5 Pamiętnik Towarzystwa Dobroczynności Krakowskiego wydany z powodu obchodzonego wd. 24 i 25 czerwca 1866 r.piećdziesiat-letniego jubileuszu wskrzeszenia w roku 1816 tegoż Towarzystwa, Kraków 1868.

6 W. Wielogłowski, O żebractwie w Krakowie, Kraków 1861, s. 4.

7 Por. Organizacya i ustawy Towarzystwa Dobroczynności Wolnego Miasta Krakowa, Kraków 1817, s. 1-5; Pamiętnik Towarzystwa Dobroczynności Krakowskiego wydany z powodu obchodzonego wd. 24 i 25 czerwca 1866 r. pięćdziesiat-letniego jubileuszu wskrzeszenia w roku 1816 tegoż Towarzystwa, dz. cyt., s. 85. W dniu otwarcia Domu Schronienia Ogólnego Towarzystwo przyjęło 150 dorosłych osób oraz 24 sieroty.

8 Por.J.T. Głębocki, Zakłady ku ulżeniu cierpieniom bliźnich obecnie w Krakowie istniejqce, dz. cyt., s. 128. 
niem dostawali oni niezbędne ubrania i pościel ${ }^{9}$. Przy kwalifikacji podopiecznych brano pod uwage miejsce zamieszkania oraz tak zwane dawne zasługi, tzn. jednym $\mathrm{z}$ warunków przyjęcia był fakt wykonywania pracy zarobkowej w czasie, kiedy było to możliwe. Zgodę na zamieszkanie w Domu Schronienia ubogi uzyskiwał, jeżeli jego życie było przykładne, zgodne z zasadami moralnymi, był pracowity i z braku sił fizycznych bądź choroby pozbawiony został możliwości zarobienia na utrzymanie. Konieczne było potwierdzenie tej sytuacji odpowiednim zaświadczeniem.

Każdy podopieczny przebywający w Domu Schronienia Ogólnego podlegał regulaminowi z 26 stycznia 1817 roku, który wyznaczał godziny snu, posiłków, odpoczynku, a także pracy ${ }^{10}$, o kolejności zajęć w Domu Schronienia informował dzwonek ${ }^{11}$. Pobudkę naznaczono na godzinę 6.00, po czym następował czas na modlitwę, mszę św., dzień kończył wspólny pacierz o godz. 20.0012. Surowo zabraniano żebrania w mieście ${ }^{13}$, a od włóczęgostwa próbowano odzwyczaić zakazując podopiecznym opuszczania zakładu przez okres jednego miesiąca ${ }^{14}$. O czystość i porządek dorośli mieli dbać sami, natomiast sale dla dzieci miały przydzieloną opiekunkę i posługiwaczkę $e^{15}$.

9 Por. AN Kraków, Posiedzenie dnia 23 lutego 1817, w: Protokót pierwszy posiedzeń Towarzystwa Dobroczynności w Krakowie od 1816 do 1827, dz. cyt., k. 20.

10 Por. AN Kraków, Protokót Wewnętrznego Urządzenia Domu mającego mieścić w sobie ubogich zawierający przepisy ogólne względem moralności, ochędóstwa, w pracy, dozoru i rozktadu godzin, sygn. TD 93, k.1-4; Wewnętrzne urzadzenie domu, na posiedzeniu delegowanych przez Towarzystwo, 26 stycznia 1817 oznaczone, w: J.T. Głębocki, Zakłady ku ulżeniu cierpieniom bliźnich obecnie w Krakowie istniejace, dz. cyt., s. 159.

11 Por. AN Kraków, Posiedzenie dnia 8 lutego 1817, w: Protokót pierwszy posiedzeń Torwarzystwa Dobroczynności w Krakowie od 1816 do 1827, dz. cyt., k. 19.

12 Por. Wewnętrzne urzadzenie domu, na posiedzeniu delegowanych przez Towarzystwo, 26 stycznia 1817 oznaczone, w: J.T. Głębocki, Zakłady ku ulżeniu cierpieniom bliźnich obecnie w Krakowie istniejące, dz. cyt., s. 159-160.

13 Por. AN Kraków, Posiedzenie dnia 11 maja 1817 r., w: Protokót pierwszy posiedzeń Towarzystwa Dobroczynności w Krakowie od 1816 do 1827, dz. cyt., k. 36.

14 Por. Rocznik Towarzystwa Dobroczynności Wolnego Miasta Krakowa z roku 1826, Kraków 1827, s. 8.

15 Por.J.T. Głębocki, Zakłady ku ulżeniu cierpieniom bliżnich obecnie w Krakowie istniejace, dz. cyt., s. 123. 
W statucie wydanym w 1839 roku zamieszczono osobny rozdział traktujący „O dozorze nad dziećmi umieszczonemi w Domu Schronienia”. Podano w nim, że „opieka nad niemi gównie zasadza się na tem, aby zostały usposobione na członków użytecznych Społeczności”16. Nadzór nad wychowaniem należał do obowiązków Wydziału Spisu ${ }^{17}$. Jak wynikało z treści statutu z 1839 roku, przyjmowano jedynie te dzieci, które nie miały skończonych 10 lat, a ich rodzice pozostawali pod opieką Towarzystwa. Opieką mogły być również otoczone sieroty lub dzieci ubogich rodziców, które wskazał Rząd Krajowy, ale zaznaczano, że powinny być one utrzymywane z osobnego funduszu, na który środki będzie przeznaczał rząd. Dzieci pozostawały w zakładzie do 12. roku życia, po tym czasie Wydział Spisu umieszczał je w domach, gdzie dziewczęta pełniły rolę służących, a chłopców kierowano na naukę rzemiosła ${ }^{18}$. Podkreślano, że „szczególniej uważać potrzeba, aby oddawane były w takie miejsca, gdzieby nie zachodziła obawa o ich zepsucie moralne, jak również aby nie marnotrawiły napróżno dalszych lat wieku swojego" ${ }^{19}$. Aby mieć kontrolę nad opuszczaniem przez sieroty zakładu, postanowiono, że oddawane będą pod opiekę wyłącznie na podstawie pisemnej zgody Wydziału Spisu. W sytuacji gdyby miejsce, w którym było umieszczone dziecko, okazało się niewłaściwe, a pobyt w nim wpływać mógłby niekorzystanie na jego rozwój, wówczas wracało ono do zakładu. W roku 1874 zmieniono zapis mówiący o wieku dzieci przyjmowanych pod opiekę Towarzystwa i zdecydowano, że opieka udzielana będzie „sierotom lub dzieciom rodziców podupadłych, do g. miasta Krakowa przynależnych, od 6 do 8 roku życia" ${ }^{20}$. Dzieciom, tak jak

16 AN Kraków, Statut urzadzający Towarzystwo Dobroczynności w Krakowie, Kraków 1839, k. 33.

17 Por. AN Kraków, Statuty Towarzystwa Dobroczynności, sygn. 547/20. Statut urzadzajacy Towarzystwo Dobroczynności w Krakowie, dz. cyt., k. 20, 22; Statut Towarzystwa Dobroczynności w Krakowie, Kraków 1901, k. 96; Biblioteka Jagiellońska, Dział Rękopisów, Instrukcja dla Dyrektora Zaktadu Towarzystwa Dobroczynności w Krakowie, k. 76-78; Instrukcja określająca obowiązi Dyrektora Towarzystwa Dobroczynności w Krakowie, k. 78-82, bez daty, sygn. 9716 III.

18 Por. AN Kraków, Statut urzqdzający Towarzystwo Dobroczynności w Krakowie, dz. cyt., k. 34.

19 Tamże, k. 35.

20 Statut Towarzystwa Dobroczynności w Krakowie (1874), dz. cyt., s. 3-4.; AN Kraków, Statut Towarzystwa Dobroczynności w Krakowie (1901), dz. cyt., k. 85. 
w poprzednich latach, zapewniano mieszkanie, wyżywienie, ubranie oraz elementarną naukę. Zajmowano się nimi do czasu zakończenia przygotowania do zatrudnienia $\mathrm{w}$,jakimś praktycznym zawodzie”21. W 1885 roku podniesiono również górną granicę wiekową, w jakim dziewczęta i chłopcy opuszczali zakład. Chłopcy oddawani byli do rzemiosła po ukończonym 14. roku życia, a dziewczęta do służby po 16. roku życia. Nadal zaznaczano, że istotne było, aby były to miejsca, gdzie nie zachodziłaby obawa o ich „zepsucie moralne”22. Stwarzano także możliwość dalszego kształcenia tym podopiecznym, którzy wyróżniali się w nauce i chcieli ją kontynuować. Na wniosek Komisji Szkolnej Rada Ogólna podejmowała decyzję o tym, że „pomocną poda rękę do szczegółowego wykształcenia”23.

Sierotom zapewniano nie tylko opiekę, ale również naukę, przynajmniej w elementarnym zakresie. Początkowo nauczycieli wybierano spośród dorosłych podopiecznych, ale po założeniu szkółki w 1820 roku w zakładzie zatrudniono stałego nauczyciela. W szkole podopieczni uczyli się religii, czytania i pisania po polsku i niemiecku, a także liczenia. Nauką dzieci miał się zajmować nauczyciel, będący tzw. urzędnikiem płatnym Towarzystwa, którego kandydaturę pozytywnie zaopiniowała Rada Ogólna ${ }^{24}$. Dziewczęta nabywały ponadto potrzebnych im umiejętności w przyszłym życiu, czym zajmowała się ochmistrzyni. Do jej obowiązków zaliczono również troskę o to, aby dzieci „zachowały ochędóstwo ciała i odzieży”25. Obowiązkiem nauczyciela było również dyscyplinowanie dzieci. Zaznaczano, że przysługiwało mu prawo wymierzenia kary cielesnej, ale nie mogła on przekraczać trzech rózg ${ }^{26}$. Po powołaniu w 1874 roku wewnętrznego organu noszącego nazwę Komisji Szkolnej w jej zakres czynności wpisano nadzór nad szkołą, nauczycielem oraz ochmistrzyniami ${ }^{27}$. Członkowie Wydziału Spisu kontrolowali ponadto pracę nauczyciela oraz ochmistrzyni, a wszel-

1 Tamże.

22 AN Kraków, Statut Towarzystwa Dobroczynności w Krakowie (1901), dz. cyt., k. 98.

23 Tamże, k. 97.

24 Por. AN Kraków, Statut urządzajacy Towarzystwo Dobroczynności w Krakowie, dz. cyt., k. 34.

25 Tamże.

26 Por. tamże, k. 28.

27 Por. Statut Towarzystwa Dobroczynności w Krakowie (1874), dz. cyt., s. 15. 
kie zastrzeżenia oraz propozycje zmian mieli oni przedstawiać Radzie Ogólnej ${ }^{28}$. W przygotowanej w 1874 roku Instrukcyi dla nauczyciela szkoty sierót w Krakowskiem Towarzystwie Dobroczynności zabroniono nauczycielowi stosowania kary cielesnej, nie mógł jej wymierzać również katecheta ani ochmistrzynie „pod osobistą odpowiedzialnością" ${ }^{29}$. Karność wśród uczniów osiągać miano wszelkimi środkami dozwolonymi ustawami szkolnymi, a zwłaszcza zachętą do cnoty i pracą. Kwestię karności dzieci poruszono również w instrukcji normującej obowiązki i przywileje Komisji Szkolnej ${ }^{30}$. Zapisano w niej, że bez zgody Komisji żadne dziecko nie mogło „być cieleśnie karanem przez kogokolwiek bądź, ani też ze szkoły, a tem samem z zakładu z jakiegobądź powodu wydalonem nie będzie" ${ }^{31}$.W Przepisach dotyczacych catodziennego zajęcia mtodzieży, które zawarto instrukcji ${ }^{32}$, przeczytać można, że starannie zaplanowany dzień wypełniony był zajęciami szkolnymi, modlitwą, nauką szycia, wyplatania, kroju. W dni wolne lub świąteczne dzieci wychodziły pod opieką ochmistrzyń na spacery za miasto, w trakcie których „praktycznie zaznajamiano z różnemi tworami przyrody" ${ }^{33}$. W niedziele i święta sieroty uczestniczyły wraz z nauczycielem i ochmistrzyniami w mszach św. w zakładowej kaplicy.

W latach 80. XIX wieku poszukiwano rozwiązania kwestii praktycznego kierunku kształcenia podopiecznych KTD i podjęto się utworzenia szkoły rzemiosł. Początkowo utworzono tzw. salę rzemios ${ }^{34}$, przy powołaniu której wzorowano się na warsztatach urządzonych w Warszawie ${ }^{35}$. Na posiedzeniu w dniu 4 kwietnia 1886

28 AN Kraków, Statut urządzający Towarzystwo Dobroczynności w Krakowie, dz. cyt., k. 35 .

29 Instrukcya dla nauczyciela szkoty sierót w Krakowskiem Towarzystwie Dobroczynności, Kraków 1874, s. 6.

30 Por. Instrykcya dla Komisyi Szkolnej w Krakowskiem Towarzystwie Dobroczynności, Kraków 1874, s. 112.

31 Tamże, s. 113.

32 Por. Instrukcya dla nauczyciela szkoty sierót w Krakowskiem Towarzystwie Dobroczynności, Kraków 1874, s. 6.

33 Tamże, s. 5.

34 Por. Rocznik Krakowskiego Towarzystwa Dobroczynności z roku 1886, Kraków 1887, s. 21-27.

35 Por. AN Kraków, Protokól z posiedzenia nadzwyczajnego Rady Ogólnej w dniu 17 maja 1885 roku, w: Ósmy Tom Protokotu Obrad Rady Ogólnej T.D. od dnia 16 września 1860 rozpoczęty, dz. cyt., k. 1082. 
roku Komisja Szkolna zgłosiła projekt „nauki rzemiosł dla chłopców, a praktycznych robót kobiecych dla dziewcząt" ${ }^{\prime 36}$. Nauka w szkole rzemiosł miała przynosić korzyści wychowawcze. Zdobyte tam umiejętności przez chłopców i dziewczęta zwiększały ich szanse na znalezienie zatrudnienia i właściwe wykorzystanie swoich sił i możliwości. Przypuszczać należy, że rozwiązanie szkoły codziennej w zakładzie było przyczynkiem do zaprzestania działalności szkoły rzemiosł ${ }^{37}$.

Jak wynika z zapisów w statutach nad karnością dorosłych podopiecznych, w Domu Schronienia czuwała Rada Ogólna ${ }^{38}$, Wydział Spisu, Wydział Ekonomiczny (przemianowany na Gospodarczy), prowizor, kontrolowali ją ponadto odwiedzający zakład tzw. Ojcowie i Matki oraz Oddział Dam. W instrukcji wydanej przez KTD zapisano, że „[...] obchodzenie się z dziećmi lub ubogimi, winno odznaczać się ze strony prowizora wszelką łagodnością i ojcowską troskliwością”39, jeżeli było to konieczne, wyznaczał on kary dorosłym ubogim ${ }^{40}$.W Statucie z 1839 roku zaznaczono, że wyznaczanie kar dla dorosłych za tzw. „mniejsze przewinienia”41 należało do prowizora ${ }^{42}$. Zaliczono do nich pijaństwo, kłótnie, oddalanie się z zakładu bez pozwolenia lub zbyt późny powrót. Karą mógł być areszt, który nie powinien trwać dłużej niż

36 Rocznik Krakowskiego Towarzystwa Dobroczynności z roku 1886, Kraków 1887, s. 21-27.

37 Por.AN Kraków, Protokoty posiedzeń z lat 1921-1940 r., sygn. TD 344, k. 390. W analizowanych protokołach posiedzeń Rady Ogólnej Towarzystwa Dobroczynności z lat 1919-1941 nie wspominano o istnieniu szkoły rzemiosł.

38 Por. AN Kraków, Statut urządzajacy Towarzystwo Dobroczynności w Krakowie, dz. cyt., k. 18. Radzie Ogólnej powierzono „zarząd nad Karnością miejscową". Statut urzadzajacy Towarzystwo Dobroczynności w Krakowie (1867), dz. cyt., k. 67; Statut Towarzystwa Dobroczynności w Krakowie (1901), dz. cyt., k. 91. Zapisano w nim, że Rada Ogólna troszczyła się o zakład starców i sierot pod względem rozmieszczenia podopiecznych, potrzeb oraz karności.

39 Przepisy wewnętrznego porzadku Domu Schronienia Ubogich Towarzystwa Dobroczynności w Krakowie, w: J.T. Głębocki, Zakłady ku ulżeniu cierpieniom bliźnich obecnie w Krakowie istniejace, dz. cyt., s. 159-160.

40 Por. Instrukcja dla prowizora, dziesiętników i odźwiernego z 1839 r., w: J.T. Głębocki, Zaktady ku ulżeniu cierpieniom bliźnich obecnie w Krakowie istniejace, dz. cyt., s. 173-174.

41 AN Kraków, Statut urzqdzający Towarzystwo Dobroczynności w Krakowie, dz. cyt., k. 31.

42 Por. AN Kraków, Posiedzenie dnia 9 marca 1817 roku, w: Protokót pierwszy posiedzeń Towarzystwa Dobroczynności w Krakowie od 1816 do 1827, dz. cyt., k. 24. Pierwszy prowizor został powołany w marcu 1817 roku. 
sześć godzin ${ }^{43}$. W przypadku innych wykroczeń prowizor informował Wydział Ekonomiczny, który rozpatrywał problem. Kary obejmowały potrącenie kilku groszy z dziennej płacy przez określony czas, zakaz wychodzenia do miasta, areszt, który nie powinien przekraczać trzech dni, ostatecznie decydowano się na wydalenie podopiecznego z Domu Schronienia ${ }^{44}$. Do prowizora należało również organizowanie pracy zarobkowej dla dorosłych ubogich ${ }^{45}$, ponadto udzielał on zgody na wyjście podopiecznego z zakładu. Wychodzący otrzymywał pisemną zgodę z wypisaną godziną powrotu, zobowiązany był do noszenia płaszcza z wyszytymi inicjałami TD, co miało uniemożliwić żebranie na mieście ${ }^{46}$. W organizacji pracy i pełnieniu powierzonej funkcji pomagali prowizorowi dziesiętnicy i odźwierni. Prowizor i osoby wspomagające go w pełnieniu obowiązków, m.in. dozorca domu ubogich, ponosili odpowiedzialność za jakikolwiek nieporządek, przejawy złych obyczajów i ewentualne zgorszenie ubogich. Mieli zgłaszać naruszanie przepisów osobom wizytującym Dom Schronienia oraz wizytować wszystkie sale ${ }^{47}$, dbać o bezpieczeństwo (np. czy ktoś nie zaprószył ognia, czy nie palił tytoniu), dbać o obyczaje (np. sprawdzać czy mężczyźni nie przechodzili do sal kobiecych, czy nie odbywali spotkań poza salami).

W pierwszej połowie XIX wieku członkowie Wydziału Ekonomicznego sprawdzali także, czy ubodzy w zakładzie spędzali czas

Por. AN Kraków, Statut urzadzający Towarzystwo Dobroczynności w Krakowie (1867), dz. cyt., k. 70. W ramach obowiązków zapisano tzw. karność domową. Kary, jakie można było wymierzać, były takie same, jak zapisane w Statucie z 1839 roku.

44 Por. AN Kraków, Posiedzenie obiorcze urzędników honorowych i płatnych T.D. w dniu 8 grudnia 1847 roku, w: Czwarty Protokót Posiedzeń Rady Ogólnej Towarzystwa Dobroczynności w Krakowie 1844, dz. cyt., k. 133; Statut urzadzajacy Towarzystwo Dobroczynności w Krakowie, dz. cyt., k. 36

45 Por. AN Kraków, Posiedzenie obiorcze urzędników honorowych i płatnych T.D. w dniu 8 grudnia 1847 roku, w: Czwarty Protokót Posiedzeń Rady Ogólnej Towarzystwa Dobroczynności w Krakowie 1844, dz. cyt., k. 133.

46 Por. tamże; Wewnętrzne urządzenie domu na posiedzeniu delegowanych przez Towarzystwo, 26 stycznia 1817 oznaczone, w: J.T. Głębocki, Zaktady ku ulżeniu cierpieniom bliznich obecnie w Krakowie istniejace, dz. cyt., s. 159-160.

47 Por. Posiedzenie obiorcze urzędników honorowych i płatnych T.D. w dniu 8 grudnia 1847 roku, w: Czwarty Protokót Posiedzeń Rady Ogólnej Towarzystwa Dobroczynności w Krakowie 1844, dz. cyt., k. 133; Posiedzenie dnia 8 lutego 1817, w: Protokót pierwszy posiedzeń Towarzystwa Dobroczynności w Krakowie od 1816 do 1827, dz. cyt., k. 18. 
wolny zgodnie $\mathrm{z}$ obowiązującymi przepisami. Osobom mogącym pracować wyszukiwali zatrudnienie, sporządzając wcześniej listę tych, którzy mogli pracować. Kontrolowali również odpowiednie wykonanie powierzonej pracy, a osoby pilnie wykonujące swoje obowiązki przedstawiali do nagrody ${ }^{48}$. W drugiej połowie XIX wieku wymierzanie kar ubogim, a także nadzór nad nimi, powierzono Wydziałowi Spisu ${ }^{49}$. Jego członkowie decydowali ponadto o rozmieszczeniu ubogich w salach, przy uwzględnieniu ich ,wieku, płci, stanu zdrowia i skłonności" ${ }^{50}$, ich zadaniem było również czuwanie nad odpowiednim wykorzystywaniem czasu przez podopiecznych.

\section{Oddział Dam oraz 0jcowie i Matki w trosce o wychowanie i opiekę nad ubogimi Towarzystwa Dobroczynności}

Troska o podopiecznych zakładu, zarówno ich potrzeby fizyczne, jak i odpowiednie zachowanie należała do Oddziału Dam Towarzystwa Dobroczynności. Ze statutów z roku 1839 oraz 1867 dowiadujemy się, że ich szczególnym zadaniem było zbieranie funduszy na rzecz ubogich Towarzystwa ${ }^{51}$. W Rocznikach Towarzystwa Dobroczynności wymieniano je jako opiekunki sal ubogich, zwłaszcza sal dzieci. W drugiej połowie XIX wieku oraz na początku wieku XX Damy nadal opiekowały się zakładem Towarzystwa, tj. salą przeznaczoną dla chorych, kuchnią, pralnią, kaplicą, a także szkołą ${ }^{52}$. Pod ich opieką był również ołtarz w Bramie Floriańskiej ${ }^{53}$. W Statucie Towarzystwa Dobroczynności z 1885 roku podkreślono, że troska Dam

Por. AN Kraków, Statut urządzający Towarzystwo Dobroczynności w Krakowie, dz. cyt., k. 25; Statut urzadzajacy Towarzystwo Dobroczynności w Krakowie (1867), dz. cyt., k. 66.

49 Por. Statut Towarzystwa Dobroczynności w Krakowie (1874), dz. cyt., s. 14; Statut Towarzystwa Dobroczynności w Krakowie (1885), dz. cyt., s. 16; Statut Towarzystwa Dobroczynności w Krakowie (1901), dz. cyt., k. 97.

$50 \quad$ Statut Towarzystwa Dobroczynności w Krakowie (1901), dz. cyt., k. 97.

51 Por. Statut urzadzajacy Towarzystwo Dobroczynnośi w Krakowie, dz. cyt., k. 12; Statut urzadzający Towarzystwo Dobroczynności w Krakowie (1867), dz. cyt., k. 55.

52 Zapraszane były np. na popisy uczniów, które odbywały się na koniec roku szkolnego.

53 Statut Towarzystwa Dobroczynności w Krakowie (1874), dz. cyt., s. 24. 
miała być ukierunkowana na odpowiednie wychowanie dziewcząt. W czasie odwiedzin w zakładzie Towarzystwa, których częstotliwości nie precyzowano ${ }^{54}$, Damy zapisywały swoje uwagi do założonej w latach 80. XIX wieku i przechowywanej w kancelarii prowizora książki ${ }^{55}$. W Statucie z roku 1901 potwierdzono, że Damy miały opiekować się szkołą, kontrolować porządek w salach, zobowiązane zostały ponadto do czuwania nad wychowaniem dziewczą $t^{56}$.

Jak wynika ze statutów, nadzorowaniem porządku, zachowania się ubogich w salach, zajmowali się również Ojcowie i Matki, czyli opiekunowie sal ${ }^{57}$. Odwiedzając zakład mieli zwracać uwagę na przestrzeganie zasad regulaminu, „sprawowanie się i ochędóstwo ubogich" ${ }^{8}$, a wszelkie propozycje wprowadzenia zmian przekazywać mieli Radzie Ogólnej. Niestety nie wszyscy zobowiązani do odwiedzania Domu Schronienia wywiązywali się z tego zadania bądź też powierzali je osobom nienależącym do Towarzystwa ${ }^{59}$.

Za kształtowanie właściwej postawy moralnej podopiecznych KTD odpowiedzialny był kapelan zakładu, który również zaliczony został do grupy tzw. urzędników płatnych. Wytyczne wydanej w 1878 roku Instrukcji dla księdza kapelana zaktadu Towarzystwa Dobroczynności precyzowały jego obowiązki duszpasterskie oraz dydaktyczne. Kapelan dbał o rozwój moralny wychowanków, czuwał nad religijnym wychowaniem dzieci, uczył religii w szkole, przygotowywał dzieci do spowiedzi, udzielał im sakramentów. Jego obowiązkiem było sprawowanie mszy św. w niedziele i święta, udział w pogrze-

54 Por. Statut Towarzystwa Dobroczynności w Krakowie (1885), s. 22-23. Zapisano, że wizyty Dam w zakładzie miały odbywać się „od czasu do czasu”.

55 Por. tamże, s. 23.

56 Por. AN Kraków, Statut Towarzystwa Dobroczynności w Krakowie (1901), dz. cyt., k. 102.

57 Por. AN Kraków, Statut urzq̨dzający Towarzystwo Dobroczynności w Krakowie, dz. cyt., k. 27.

58 AN Kraków, Statut urzqdzajacy Towarzystwo Dobroczynności w Krakowie (1867), dz. cyt., k. 67; Statut Towarzystwa Dobroczynności w Krakowie (1874), dz. cyt., s. 24; Statut Towarzystwa Dobroczynności w Krakowie (1901), dz. cyt., k. 103.

59 Por. AN Kraków, Posiedzenie dnia 27 lipca 1817, w: Protokót pierwszy posiedzeń Towarzystwa Dobroczynności w Krakowie od 1816 do 1827, dz. cyt., k. 44. 
bach, udzielanie sakramentów ${ }^{60}$. W gestii kapelana była troska o kaplicę zakładową oraz wszelkie jej uposażenie ${ }^{61}$. Zwyczajem KTD było rozpoczynanie i uroczyste kończenie roku szkolnego mszami, w których uczestniczyli członkowie KTD, zaproszone osoby oraz podopieczni zakładu, w kaplicy odbywały się wtedy msze i nabożeństwa za zmarłych dobroczyńców ${ }^{62}$. Kaplicę w Domu Schronienia na Wawelu zorganizowano już 9 listopada 1817 roku w dolnych partiach Zamku, gdzie codziennie odprawiano w niej mszę św. ${ }^{63}$. Umieszczono w niej tryptyk przedstawiający Matkę Boską z dzieciątkiem Jezus, który był darem pochodzącym z kaplicy dawnego zakładu Bractwa Panny Marii ${ }^{64}$. W celu umożliwienia ubogim odbywania codziennych modlitw, w latach 1854-1855 urządzono kaplicę również w zakładzie mieszczącym się w domu Koletek ${ }^{65}$. Arcybractwo Niepokalanego Poczęcia N.P. Marii jako dar ofiarowało kielich z pateną, natomiast Zgromadzenie Sióstr Franciszkanek

60 Por. Instrukcya dla ks. kapelana Zaktadu Towarzystwa Dobroczynności, Kraków 1878, s. 3; AN Kraków, Posiedzenie obiorcze w dniu 9 grudnia 1856 r. odbyte, w: Piaty Tom Protokotu obrad Rady Ogólnej Towarzystwa Dobroczynności w Krakowie od roku 1855, TD 6, k. 159. Jeszcze w 1854 roku przypominano wydanym rozporządzeniem, aby ubodzy regularnie, corocznie odbywali spowiedź wielkanocną.

${ }^{61}$ Por. Instrukcya dla ks. kapelana Zakładu Towarzystwa Dobroczynności, Kraków 1878, s. 5.

62 Por. Archiwum Kurii Metropolitarnej w Krakowie, Zaproszenie do wzięcia udziatu na Mszy św. za duszęs.p. Antoniego Rozmanitha i jego syna, która odbędzie się w kaplicy zaktadu Towarzystwa Dobroczynności w Krakowie, ul. Koletek 12, dnia 13 czerwca 1919, sygn. ABS 243; AN Kraków, Posiedzenie obiorcze w dniu 9 grudnia 1859 r. odbyte, w: Piaty Tom Protokotu obrad Rady Ogólnej Towarzystwa Dobroczynności w Krakowie od roku 1855, dz. cyt., k. 644.

63 Por. AN Kraków, Posiedzenie dnia 14 września 1817, w: Protokót pierwszy posiedzeń Towarzystwa Dobroczynności w Krakowie od 1816 do 1827, dz. cyt., k. 52; Posiedzenie XXX dnia 12 października 1817, w: Protokót pierwszy posiedzeń Towarzystwa Dobroczynności w Krakowie od 1816 do 1827, dz. cyt., k. 57.

64 Por. K. Hoszowski, Wiadomość historyczna o starożytnym obrazie N. Panny Marii w kaplicy Domu Schronienia ubogich Koletki zwanym tudzież o szpitalu krakowskim a raczej Domu Schronienia Ubogich pod imieniem Bractwa Panny Marii, niegdyś przy ul. św. Szczepana istniejącym, Kraków 1857, s. 2.

65 Por. AN Kraków, Posiedzenie obiorcze w dniu 9 grudnia 1856 r. odbyte, w: Piaty Tom Protokotu obrad Rady Ogólnej Towarzystwa Dobroczynności w Krakowie od roku 1855, dz. cyt., k. 159. Od lat 60. XIX wieku mieścił się tam zakład, po zapisie testamentowym Ignacego Rotarskiego. 
przy kościele św. Andrzeja podjęło prace nad odrestaurowaniem kilkunastu ornatów ${ }^{66}$.

W latach 90. XIX wieku opracowano kolejny regulamin normujący zasady pobytu w Domu Schronienia. W wydanych w roku 1891 Przepisach dotyczacych wewnętrznego urzadzenia Domu Schronienia ubogich zostajacych pod opiekq Towarzystwa Dobroczynności $w$ Krakowie ${ }^{67}$, będących uzupełnieniem i rozszerzeniem dotychczas obowiązującego regulaminu, podtrzymano zapis o surowym zakazie żebrania, którego lekceważenie mogło przynieść konsekwencje w postaci wydalenia z Domu Schronienia ${ }^{68}$. KTD, starając się o zaspokojenie podstawowych potrzeb ubogich, dbało o "pociechę religijną” oraz wychowanie sierot na „pożytecznych członków społeczeństwa” ${ }^{\text {. }}$.

\section{Opieka i wychowanie realizowane przez Siostry Miłosierdzia w zakładzie Krakowskiego Towarzystwa Dobroczynności}

Początek XX wieku przyniósł zmiany w zakresie opieki na dziećmi w zakładzie KTD. Na zebraniu Dam w dniu 2 stycznia 1902 roku prezes Towarzystwa poinformował, że do zakładu sierot wprowadzono Siostry Miłosierdzia ${ }^{70}$, które zastąiłiły świeckie ochmistrzynie w opiece nad dziećmi, jak również przejęły obowiązki w kuchni, pralni i infirmerii. W przygotowanej Instrukcji tymczasowej dla Sióstr Mitosierdzia w Zaktadzie Towarzystwa Dobroczynności w Krakowie

66 Por. AN Kraków, Posiedzenie zwyczajne w dniu 18 lutego 1855 roku, w: Czwarty Protokót Posiedzeń Rady Ogólnej Towarzystwa Dobroczynności w Krakowie 1844, dz. cyt., k. 865.

67 AN Kraków, Przepisy dotyczace wewnętrznego urządzenia Domu Schronienia ubogich zostajacych pod opiekq Towarzystwa Dobroczynności w Krakowie z 4.X.1891, sygn. TD 112.

68 Tamże.

69 Rocznik Krakowskiego Towarzystwa Dobroczynności z roku 1901, Kraków 1902, s. 36.

70 Por. AN Kraków, Protokół ze Zgromadzenia Dam Towarzystwa Dobroczynności które się odbyło dnia 2 stycznia 1902 o godzinie 4tej popołudniu w mieszkaniu Prezesowej Dam hr Andrzejowej Potockiej w pałacu pod Baranami w rynku głównym 1. 27, w: Protokoty z zebrania Ogólnego Dam i cztonków krakowskiego Towarzystwa Dobroczynnego, sygn. 13, k. 107. 
dla starców $i$ sierot ${ }^{71}$ określono wstępnie zakres obowiązków sióstr. Zanotowano w niej, że wychowując dzieci miały kierować się zasadami religii katolickiej. W porozumieniu z Komisją Szkolną układały plany zajęć dzieci poza godzinami szkolnymi, ćwiczeń gimnastycznych i zajęć podczas odpoczynku ${ }^{72}$. Uszczegółowione zapisy podano w Instrukcyi określającej obowiązki Zgromadzenia Sióstr Mitosierdzia wobec Towarzystwa Dobroczynności w Krakowie ${ }^{73}$. W ich gestii było również organizowanie zajęć dla dzieci i starców ${ }^{74}$.

Siostry Miłosierdzia miały czuwać nad moralnym i obyczajnym zachowaniem podopiecznych, a także troszczyć się o dyscyplinę domową. Zaznaczono w instrukcji, że Siostry miały obchodzić się z ubogimi „łagodnie, uprzejmie i z macierzyńską troskliwością" ${ }^{2}$, postępować miały ,jednak z zachowaniem należytej powagi i karności”76. Za niewłaściwe zachowanie podopieczni mogli być skarceni, miało im być udzielone upomnienie, gdyby to nie przynosiło efektu, wówczas poinformowany miał być Wydział Spisu. Wymierzał on wówczas odpowiednią karę, zgodnie z zapisami statutu, lub przedstawiał wniosek Radzie Ogólnej o wydalenie z zakładu. Codziennym obowiązkiem była msza św., wspólny pacierz, zobowiązywano też do uczestnictwa nabożeństwach majowych, odmawiania różańca i godzinek. Ubogich obowiązywał szacunek wobec przełożonych i uprzejmość wobec siebie $^{77}$. W zakładzie na początku XX wieku, tak jak w latach poprzednich, przestrzegano rozdzielności płci przy umieszczaniu podopiecznych w salach ${ }^{78}$. Dzieci obowiązywał zaplanowany dla nich porządek całodziennych zajęc ${ }^{79}$.

71 AN Kraków, Instrukcja tymczasowa dla Sióstr Mitosierdzia w Zaktadzie Towarzystwa Dobroczynności w Krakowie dla starców i sierot, sygn. 547/26, k. 421.

72 Por. tamże, k. 425.

73 AN Kraków, Instrukcya określająca obowiązki Zgromadzenia Sióstr Mitosierdzia wobec Towarzystwa Dobroczynności w Krakowie, sygn. 547/26, k. 335.

74 Tamże, k. 346-347.

75 Tamże, k. 350.

76 AN Kraków, Regulamin domu schronienia dla starców i sierot pozostających pod opieka Towarzystwa Dobroczynności, sygn. 547/26, k. 1130.

77 Por. tamże, k. 1085, 1089, 1118.

78 Por. AN Kraków, Porzqdek domowy obowiqzujacy w zakładzie wychowawczym dla sierot, sygn. 547/26, k. 1125.

79 Por. tamże, k. 1126-1127. 
Kształtowanie właściwych zachowań podopiecznych realizowane było w Krakowskim Towarzystwie Dobroczynności również poprzez wspieranie i nagradzanie podopiecznych właściwie się zachowujących, chętnie podejmujących pracę, wykonujących ją solidnie ${ }^{80}$. Nagradzano za dobre wyniki $\mathrm{w}$ nauce ${ }^{81}$, formą nagrody było również wnioskowanie o zgodę Rady Ogólnej na dalszą edukację wychowanków wybitnie uzdolnionych ${ }^{82} . Z$ protokołu posiedzeń Rady Ogólnej z dnia 15 października 1917 roku dowiadujemy się, że dzieci przebywające pod opieką Towarzystwa miały umożliwiony kontakt z rodziną i zazwyczaj podczas wakacji sześć sierot pozostawało u swych rodzin przez okres jednego miesiąca ${ }^{83}$. W Instrukcyi dla nauczyciela szkoty sierót w Krakowskiem Towarzystwie Dobroczynności zapisano, że obowiązkiem nauczyciela było urządzanie dla dzieci majówek. Pomagać mu w tym mieli kapelan i ochmistrzynie, a o prowiant miała dbać „przedsiębiorczyni żywienia dzieci” ${ }^{\text {, }}$, czyli osoba zajmująca się zakupem żywności do zakładu. Dobroczyńcy zaopatrywali sieroty w potrzebne im na majówki różnego rodzaju artykuły żywnościowe, na ten cel przekazywali również ofiary pieniężne. Dzieci w dni wolne od nauki zabierano na spacery poza miasto, wychodziły one pod nadzorem ochmistrzyń, zaznaczano przy tym, żeby nie udawały się w te miejsca, gdzie zwyczajowo zbierali się mieszkańcy Krakowa.

80 Por. AN Kraków, Sesja dnia 26 lutego 1843 r., w: Czwarty Protokót Posiedzeń Rady Ogólnej Towarzystwa Dobroczynności w Krakowie 1844, dz. cyt., k. 21. Rada Ogólna, wprowadzając prace dobrowolne w Domu Schronienia, zastrzegała, aby nie były one zbyt obciążające fizycznie. Ubodzy zajmowali się darciem pierza, wykonywaniem bandaży, przędzeniem wełny, wyrabianiem skarpetek, pończoch i kaftaników na drutach.

81 Por. AN Kraków, Protokół z posiedzenia zwyczajnego Rady Ogólnej Krakowskiego Towarzystwa Dobroczynności w dniu 18 czerwca 1876, w: Ósmy Tom Protokotu Obrad Rady Ogólnej T.D. od dnia 16 września 1860 rozpoczęty, dz. cyt., k. 149, 703, 1809.

82 Por. AN Kraków, Protokół z posiedzenia R.O. Towarzystwa Dobroczynności spisany dnia 17 czerwca 1918, w: Protokót z posiedzeń Rady Ogólnej Towarzystwa Dobroczynności poczquwszy od Stycznia 1909, sygn. TD 319, k. 244.

83 Por. AN Kraków, Protokół z posiedzenia R.O. Towarzystwa Dobroczynności spisany dnia 15 października 1917, w: Protokót z posiedzeń Rady Ogólnej Towarzystwa Dobroczynności poczquszy od Stycznia 1909, dz. cyt., k. 219.

${ }^{84}$ Instrukcya dla nauczyciela szkoty sierót w Krakowskiem Towarzystwie Dobroczynności, Kraków 1874, s. 5. 


\section{Zakończenie}

Krakowskie Towarzystwo Dobroczynności należało do grona najstarszych towarzystw dobroczynnych na ziemiach polskich pod zaborami ${ }^{85}$. Organizowało opiekę dla osób ubogich, ludzi starszych, chorych, niesprawnych fizycznie oraz kilku- i kilkunastoletnich sierot. Podopieczni stanowili zróżnicowaną wiekowo i doświadczoną niejednokrotnie wieloma problemami grupę ludzi. Tym, co charakteryzowało pracę wychowawczą prowadzoną w zakładzie, to ciągłość opieki, zaspokojenie podstawowych potrzeb, troska o polepszenie zdrowia ubogich, ale również utrwalanie pozytywnych nawyków, przy jednoczesnej zmianie niekorzystnych przyzwyczajeń. Formy pracy niejednokrotnie modyfikowano, uwzględniając zdobyte doświadczenia i wiedzę. W wygłaszanych przemowach prezesów KTD, wiceprezesów, spisywanych życiorysach postaci aktywnie wspierających pracę dobroczynną Towarzystwa podkreślano wartości religijne i moralne, wagę kierowania się zasadami wiary chrześcijańskiej w codziennym życiu podopiecznych oraz $\mathrm{w}$ pracy $\mathrm{z}$ ubogimi.

Podsumowując niniejsze rozważania, można wskazać główne obszary prowadzonej pracy wychowawczej w zakresie umoralniania podopiecznych oraz kształtowania właściwej postawy religijnej. Do najważniejszych należy zaliczyć:

- udział w mszach św., nabożeństwach, modlitwach;

- zapewnianie podopiecznym elementarnego wykształcenia i przygotowanie do zawodu;

- opiekę nad wychowankami opuszczającymi zakład;

- zachęcanie do aktywnego i pożytecznego spędzania czasu wolnego, polegającego zwłaszcza na wykonywaniu pracy nieprzekraczającej możliwości fizycznych podopiecznych oraz na czytaniu i wysłuchiwaniu treści odpowiednio dobranych lektur;

- przeciwdziałanie deprawującemu wpływowi środowiska poprzez zakaz żebrania;

- walkę z nadużywaniem alkoholu;

- naukę samodyscypliny, wdrażanie do przestrzegania porządku dnia;

85 Encyklopedia katolicka, red. F. Gryglewicz, R. Łukaszyk, Z. Sułowski, t. 1, Lublin 1973, k. 1391. 
zachęcanie do kierowania się wyższymi wartościami poprzez odwoływanie się do zasad religii chrześcijańskiej, miłości bliźniego (piętnowanie kłótliwości, awanturnictwa, zakłócania czasu innym osobom);

n troskę o dobre obyczaje i kultywowanie tradycji chrześcijańskich.

\section{BIBLIOGRAFIA}

Barnaś E., Powstanie i pierwsze lata dziatalności Krakowskiego Towarzystwa Dobroczynności (1816-1820), „Zeszyty Naukowe WSP w Rzeszowie.Pedagogika. Psychologia” 1997, z. 3.

Barnaś-Baran E., Publiczny wizerunek krakowskich dobroczyńców ludzkości w XIX w., w: Mę̇̇czyzna w rodzinie i spoteczeństwie. Ewolucja ról w kulturze polskiej i europejskiej, t. 1: Od średniowiecza do początków XX wieku, red. K. Kabacińska, K. Ratajczak, Wydawnictwo Poznańskie, Poznań 2010.

Bąk J., Opieka spoteczna nad sierotami w Krakowskim Towarzystwie Dobroczynności w latach 1816-1916, „Rocznik Krakowski” 1975, t. 46.

Czwarty Protokót Posiedzeń Rady Ogólnej Towarzystwa Dobroczynności w Krakowie 1844, nr zespołu 547, sygn. TD 4, rękopis.

Encyklopedia katolicka, red. F. Gryglewicz, R. Łukaszyk, Z. Sułowski, t. 1, Towarzystwo Naukowe KUL, Lublin 1973.

Głębocki J.T., Zakłady ku ulżeniu cierpieniom bliżnich obecnie w Krakowie istniejące. Z krótka wzmiankq o dawniejszych, a dzis nie istniejących instytucyach tego rodzaju, Czcionkami drukarni „Czasu”, Kraków 1852.

Haratyk A., Rozwój opieki nad dziećmi i mtodzieżq w Galicji doby autonomicznej, Instytut Pedagogiki Uniwersytetu Wrocławskiego, Wrocław 2002.

Hoszowski K., Wiadomośc historyczna o starożytnym obrazie N. Panny Marii w kaplicy Domu Schronienia ubogich Koletki zwanym tudzież o szpitalu krakowskim a raczej Domu Schronienia Ubogich pod imieniem Bractwa Panny Marii, niegdyś przy ul. św. Szczepana istniejacym, W Drukarni „Czasu” M. Kirchmayera, Kraków 1857.

Instrukcja dla Dyrektora Zaktadu Towarzystwa Dobroczynności w Krakowie, BJ, sygn. 9716 III, rękopis.

Instrukcja określająca obowiazki Dyrektora Towarzystwa Dobroczynności w Krakowie, BJ, sygn. 9716 III, rękopis.

Instrukcja tymczasowa dla Sióstr Mitosierdzia w Zaktadzie Towarzystwa Dobroczynności w Krakowie dla starców i sierot, nr zespołu 547, sygn. 26, rękopis.

Instrukcya dla ks. kapelana Zaktadu Towarzystwa Dobroczynności, Czcionkami Drukarni „Czasu”, Kraków 1878.

Instrukcya dla nauczyciela szkoty sierót w Krakowskiem Towarzystwie Dobroczynności, Czcionkami Drukarni „Czasu”, Kraków 1874.

Instrukcya określająca obowiqzzki Zgromadzenia Sióstr Mitosierdzia wobec Towarzystwa Dobroczynności w Krakowie, sygn. 547/26, rękopis. 
Instrykcya dla Komisyi Szkolnej w Krakowskiem Towarzystwie Dobroczynności, Czcionkami Drukarni „Czasu”, Kraków 1874.

Kępski C., Idea mitosierdzia a dobroczynność i opieka, Wydawnictwo UMCS, Lublin 2002.

Łętowski L., Wspomnienia pamiętnikarskie, Zakład Narodowy im. Ossolińskich, Wrocław 1956.

Markiewiczowa H., Dziatalność opiekuńczo-wychowawcza Warszawskiego Towarzystwa Dobroczynności 1814-1914, Wydawnictwo Akademii Pedagogiki Specjalnej, Warszawa 2002.

O Towarzystwie Dobroczynności i innych bogobojnych zaktadach w Krakowie, „Dzieje Dobroczynności Krajowey i Zagraniczney z wiadomościami ku jej wydoskonaleniu służącemi” 1822.

Organizacya i ustawy Towarzystwa Dobroczynności Wolnego Miasta Krakowa, Drukarnia Jana Maja, Kraków 1817.

Ósmy Tom Protokotu Obrad Rady Ogólnej T.D. od dnia 16 września 1860 rozpoczęty, nr zespołu 547, sygn. TD 8, rękopis.

Pamiętnik Towarzystwa Dobroczynności Krakowskiego wydany z powodu obchodzonego w d. 24 i 25 czerwca 1866 r. pięćdziesiat-letniego jubileuszu wskrzeszenia w roku 1816 tegoż Towarzystwa, Nakładem członków Towarzystwa Dobroczynności, Kraków 1868.

Piaty Tom Protokotu obrad Rady Ogólnej Towarzystwa Dobroczynności w Krakowie od roku 1855, nr zespołu 547, sygn. TD 6, rękopis.

Piotrowska-Marchewa M., Nędzarze i fllantropi. Problem ubóstwa w polskiej opinii publicznej w latach 1815-1863, Wydawnictwo Adam Marszałek, Toruń 2004.

Porzadek domowy obowiqzujacy w zaktadzie wychowawczym dla sierot, $\mathrm{nr}$ zespołu 547, sygn. 26, rękopis.

Protokót pierwszy posiedzeń Towarzystwa Dobroczynności w Krakowie od 1816 do 1827, nr zespołu 547, sygn. TD 7, rękopis.

Protokót Wewnętrznego Urządzenia Domu mającego mieścić w sobie ubogich zawierajacy przepisy ogólne względem moralności, ochędóstwa, w pracy, dozoru i rozktadu godzin, nr zespolu 547, sygn. TD 93.

Protokoty posiedzeń z lat 1921-1940, nr zespołu 547, sygn. 11, maszynopis.

Protokoty posiedzeń Rady Ogólnej Towarzystwa Dobroczynności od 1892 do 1908, nr zespołu 547, sygn. TD 1, rękopis.

Protokoty z zebrania Ogólnego Dam i cztonków krakowskiego Towarzystwa Dobroczynnego, nr zespołu 547, sygn. 13, rękopis.

Przepisy dotyczace wewnętrznego urzqdzenia Domu Schronienia ubogich zostajacych pod opiekq Towarzystwa Dobroczynnosici w Krakowie z 4.X.1891, nr zespołu 547, sygn. TD 112.

Puszka A., Dziatalność opiekuńczo-wychowawcza Zakonu Sióstr Mitosierdzia Wincentego à Paulo w Lublinie w XIX i XX wieku, Wydawnictwo KUL, Lublin 2013.

Regulamin domu schronienia dla starców $i$ sierot pozostających pod opieka Towarzystwa Dobroczynności, nr zespołu 547, sygn. 26. 
Rocznik Krakowskiego Towarzystwa Dobroczynności z roku 1886, W Drukarni „Czasu”, Kraków 1887.

Rocznik Krakowskiego Towarzystwa Dobroczynności z roku 1901, W Drukarni „Czasu”, Kraków 1902.

Rocznik Towarzystwa Dobroczynności Wolnego Miasta Krakowa z roku 1826, W drukarni akademickiéj, Kraków 1827.

Skowron R., Towarzystwo Dobroczynności. Organizacja i dziatalność ogólnego domu schronienia ubogich na Wawelu (1816-1846), „Studia do Dziejów Wawelu" 1991, R. 5.

Statut Towarzystwa Dobroczynności w Krakowie, Czcionkami Drukarni „Czasu”, Kraków 1874.

Statut Towarzystwa Dobroczynności w Krakowie, Czcionkami Drukarni „Czasu”, Kraków 1885.

Statut Towarzystwa Dobroczynności w Krakowie, Czcionkami Drukarni „Czasu”, Kraków 1901.

Statut urzadzajacy Towarzystwo Dobroczynności w Krakowie, Drukarnia „Czasu”W. Kirchmayera, Kraków 1867.

Statut urzq̨dzajacy Towarzystwo Dobroczynności w Krakowie, Drukiem D.E. Friedlein, Kraków 1839.

Szósty Tom Protokotu Obrad Rady Ogólnej T.D. od dnia 16 września 1860 rozpoczęty, nr zespołu 547, sygn. TD 8, rękopis.

Urząd Wojewódzki Krakowski, Sygn. UW II 1098, Rejestracja stowarzyszeń z terenu Krakowa 1945-1950 (1951), IV/3/Krm/39/45, rękopis.

Wielogłowski W., O żebractwie w Krakowie, Księgarnia Katolicka, Kraków 1861.

Zaproszenie do wzięcia udziatu na Mszy św. za dusze s.p. Antoniego Rozmanitha i jego syna, która odbędzie się w kaplicy zaktadu Towarzystwa Dobroczynności w Krakowie, ul. Koletek 12, dnia 13 czerwca 1919, sygn. ABS 243.

\section{ADRES DO KORESPONDENCJI:}

Dr Ewa Barnaś-Baran

Uniwersytet Rzeszowski

Wydział Pedagogiczny, Zakład Historii i Teorii Wychowania

ewa.bb@ur.edu.pl 